\title{
Land Recycling, Community Revitalization, and Distributive Politics: An Analysis of EPA Brownfields Program Support
}

\author{
Matthew Dull and Kris Wernstedt
}

This article examines social, economic, and political factors influencing the distribution of resources to local governments under the EPA Brownfields Program, an innovative federal effort to encourage the remediation and redevelopment of contaminated properties. Signed into law in 2002, the Small Business Liability Relief and Brownfields Revitalization Act provided the program with a congressional mandate, new tools to promote reuse such as liability protections, and increased funding up to a level of $\$ 250$ million per year. This article contributes to research on environmental regulatory reform with an analysis of successful and unsuccessful local government applicants for EPA Brownfields Program support between 2003 and 2007. Building on prior research, we develop a series of expectations and an empirical model, and estimate the influence of program priorities, government and civic capacity, interest group pressures, and institutional politics. Results point to significant relationships between program priorities and award patterns. Contrary both to EPA's explicit commitments to equity and to analysis of pre-2003 award patterns, however, we find negative correlations between the proportions of local populations that are nonwhite or low-income and the likelihood of receiving an award. In addition, better-resourced governments and several dimensions of political representation show strong associations with the likelihood of winning awards. We conclude by discussing implications.

KEY WORDS: environmental policy, environmental regulation, hazardous waste, federal grants, voluntary action, distributive politics

\section{Introduction}

Brownfields are underutilized and often contaminated land, defined in federal law as "real property, the expansion, redevelopment, or reuse of which may be complicated by the presence or potential presence of a hazardous substance, pollutant, or contaminant" (42 USC 89601 , amended 2002). Once home to the factories and warehouses that formed the core of American industry, hundreds of thousands of brownfield sites now lie scattered across the United States. ${ }^{1}$ Over the last two decades, a range of innovative local, state, and federal government policies have promoted the redevelopment of these properties using voluntary and market-based policy instruments, departing from traditional regulatory strategies. ${ }^{2}$ For advocates, 
brownfields policies represent more than environmental cleanup; they are locally driven "land recycling" - with the promise to transform distressed sites across the U.S. from blight to valuable economic and environmental resources.

Since 1993, the U.S. Environmental Protection Agency (EPA) has awarded over $\$ 800$ million in grants and loans to assess and clean up brownfields sites. ${ }^{3}$ Initially a pilot, the EPA Brownfields Program was expanded and given statutory footing by Small Business Liability Relief and Brownfields Revitalization Act of 2002. The new law provided liability relief to parties undertaking brownfields redevelopment and authorized \$250 million in annual federal support for the EPA Brownfields Program. ${ }^{4}$ Since then, more than 4,000 applications have been submitted to the Brownfield Program for support. Priorities guiding the competitive allocation of Program funding continued those of the pilot project efforts: economic and environmental benefits, community involvement, environmental justice considerations, and the effect of the brownfields redevelopment on the surrounding community (Solitare \& Greenberg, 2002).

This article describes an empirical model analyzing the distribution of EPA Brownfields Program resources to local government applicants between 2003 and 2007. We draw on an original dataset of EPA Brownfields applicant and project data obtained through Freedom of Information Act (FOIA) requests and additional public sources, including U.S. Census of Population and Census of Governments and several other sources. Through an empirical analysis of social, economic, and political factors associated with applicants and award winners, we aim to illuminate the degree to which environmental protection and revitalization objectives as well as other factors reflect program objectives. The study contributes to three fields of inquiry: policy and planning research addressing brownfields policies (Wernstedt, Meyer, \& Alberini, 2006); research on policies promoting private voluntary environmental behavior (Lyon \& Maxwell, 2004); and the broader research literature on the administration of federal grant programs (Beam \& Conlan, 2002; Collins \& Gerber, 2008).

\section{EPA Brownfields Program: Context and Development}

The EPA Brownfields Program and the profusion of local and state brownfields policies respond in part to the consequences of federal and state laws imposing liability on parties for environmental cleanup, notably the 1980 federal Comprehensive Environmental Response, Compensation, and Liability Act (Superfund) and its state counterparts. These laws and subsequent court decisions impose cleanup liability on a wide range of entities involved with a contaminated property, including those responsible for contamination, subsequent owners, prospective purchasers, and lenders. Consequently, parties often opt not to transact or develop sites believed to be contaminated, fearing liability for expensive cleanups or exposure to civil litigation. Left unattended, however, these sites may threaten public health and the environment and depress local neighborhoods.

Early efforts to promote brownfields remediation and redevelopment took hold during the decade of the 1980s, as the consequences of the broad transfor- 
mation of the U.S. economy from manufacturing and production to serviceoriented industries became increasingly apparent. Manufacturing industries were particularly hard hit during the recession of the early 1990s, prompting new pressure on policymakers to address the blight of abandoned commercial and industrial properties (Greenberg \& Issa, 2005). It was during this period that advocates began applying the term "brownfields" to differentiate these contaminated properties from "greenfields," on the one hand, and more seriously contaminated Superfund sites on the other. In 1993, EPA Administrator Carol Browner initiated the first EPA brownfields pilot grants in response to the direct advocacy of local and state officials concerned with the impact on their communities (Shehan \& Coley, 2002).

The EPA Brownfields Program is part of a broader integration of economic and environmental priorities in federal government hazardous waste policy (Greenberg \& Issa, 2005; Hula, 2001). Some observers question the balance of these priorities. Some challenge the appropriateness of an EPA-administered economic development program, suggesting that the program may be most successful at distributing resources to bolster economic development. ${ }^{5}$ Yet, this distributive logic is constrained by real limits on the financial support available under the Brownfields Program. Assessment and remediation comprise 10 percent or less of capital investment costs in brownfields projects on average, and in many projects, the maximum $\$ 200,000$ grant will constitute only 2 or 3 percent of capital needs and not significantly alter project pro-formas (Council for Urban Economic Development, 1999; Heberle \& Wernstedt, 2006; Wernstedt et al., 2006). Narrow eligibility requirements and the strings-paperwork and reporting-accompanying federal dollars further limit the program's appeal. Why then does the Brownfields Program attract so many applicants? Beyond the immediate financial support and the tacit public commitment to a project that such support may suggest (Wernstedt \& Hersh, 2006), local actors pursuing Brownfields grants respond to a variety of professional and organizational values. Winning a Brownfields award symbolizes and perhaps even motivates local attention to revitalization issues. As a competitive grant process, the EPA Brownfields Program is designed not just to accomplish environmental and economic objectives using strategies responsive to local conditions, but to achieve these ends through local initiative and the coordinated effort of private and public actors across layers of governance.

The role of local governments in promoting brownfields reuse and, in some cases, taking an assertive role in regulating environmental cleanup is welldocumented. Empirical research points to local knowledge, connections to state and federal agencies, support from local politicians, and civic engagement among the factors influencing redevelopment success (Lange \& McNeil, 2004a; Wernstedt \& Hersh, 2006). Fortney (2006) contends that locally run cleanup programs can benefit from the infusion of local knowledge, promoting the safe reuse of contaminated lands. Dana (2005) advocates amending the national Superfund law to promote the development of state-based indicators to track the implementation and results of brownfields projects. In promoting the development of state programs as "laboratories for democracy," he contends that shared indicators would further civic 
engagement around contaminated sites by defining societal values and establishing accepted standards by which to evaluate whether objectives are being reached. ${ }^{6}$

A substantial and growing body of empirical research examines the social, political, and economic dimensions of federal and state cleanup programs. Building on a broader research tradition analyzing agency administrative process, this established literature investigates the interplay of distributive politics and environmental risk in site prioritization and cleanup decisions under the federal Superfund program (Daley \& Layton, 2004; Hamilton \& Viscusi, 1999; Hird, 1994; Mazmanian \& Morell, 1992; Nakamura \& Church, 2003). In a study of state voluntary remediation programs, Daley (2007) finds that state program adoption is influenced by the severity of local contamination, local interest group pressure, and adjacency to states that have already adopted similar voluntary programs. Analyzing the distribution of EPA Brownfields Program pilot awards between 1995 and 2002, Greenberg and Hollander (2006) and Greenberg and Issa (2005) observe that, consistent with the program's mandate, communities with heavy manufacturing legacies and concentrated economically disadvantaged populations of color were more likely to receive awards and to receive them early in the EPA's awards cycle. In addition, the authors find robust local public sector capacity and strong ties to state and federal decision makers influenced the timing and likelihood of an award. The analysis presented in this article builds on and extends this research by examining local government applicants to EPA's Brownfields Program from 2003 through 2007.

To illustrate the scope of the Brownfields Program in the years we investigate, Figure 1 depicts the number of applicants and award winners across different applicant types. Roughly 4,200 applications for support were submitted to EPA from local, county, state, tribal, and territorial governments; port authorities; and redevelopment organizations during the 2003 to 2007 period. Local municipal governments represent a simple majority, about 53 percent, of all applicants, with local redevelopment authorities constituting another 14 percent. County and state government applicants together account for 14 percent of applicants. Figure 1 also highlights rates of success, roughly one-third across all applicant types during the five-year period. ${ }^{8}$ Several observations augment these aggregate numbers.

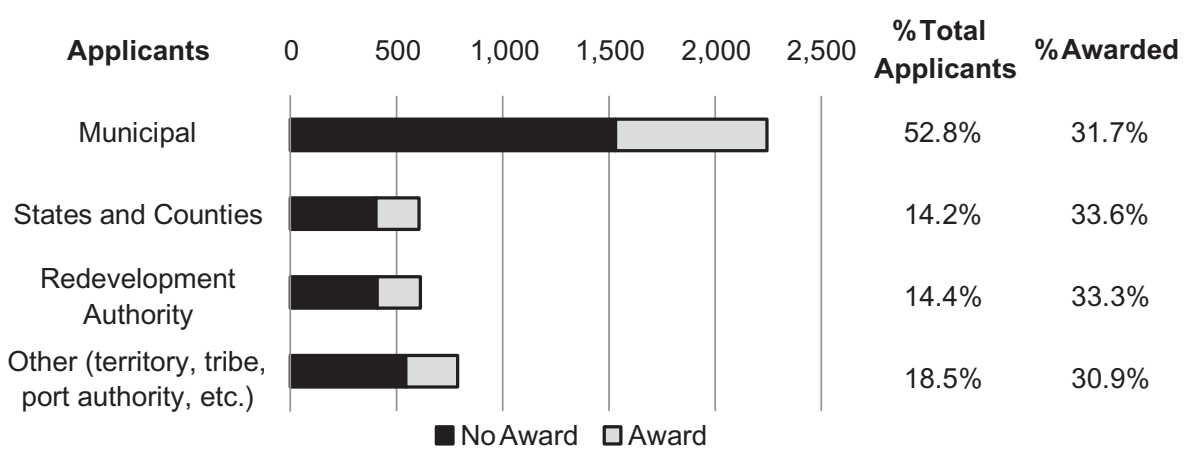

Figure 1. EPA Brownfields Applicants by Applicant Type, 2003-2007. 


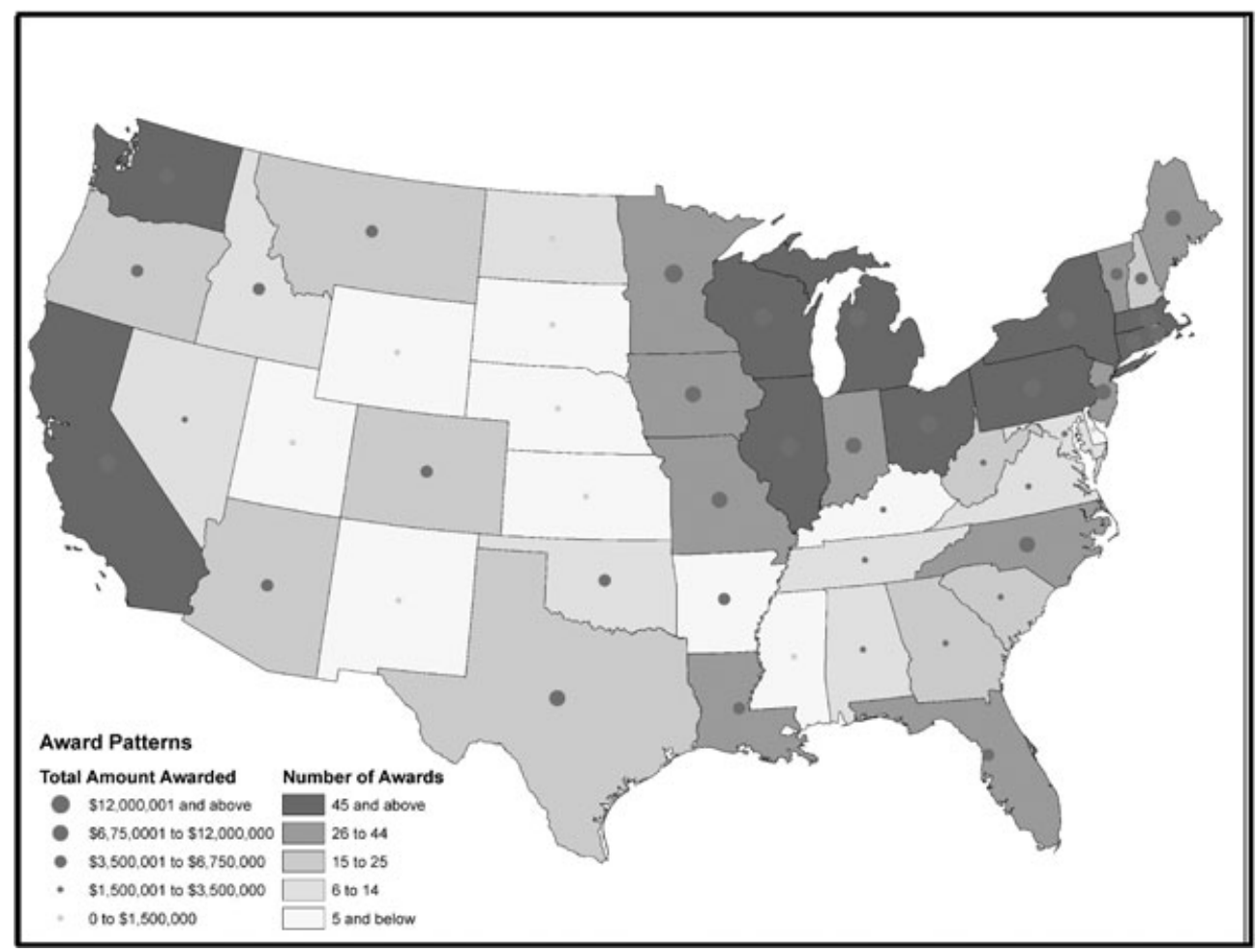

Figure 2. Distribution of EPA Brownfield Awards to Local Government Applicants (2003-2009).

First, two-thirds of applications over the period did not win awards, in part reflecting program resource limitations. Actual awards from the EPA Brownfields Program from 2003 through 2007 averaged only slightly more than $\$ 90$ million/year, with another $\$ 50$ million/year typically going to states and $\$ 25$ million to administrative expenses. These total annual appropriations of roughly $\$ 165$ million/year thus constitute only two-thirds of authorized levels. Despite broad congressional backing for the 2002 legislation, failure to fully fund the program signals potentially mixed and uncertain support for the program among political actors, and brings to the fore political and institutional factors that must be addressed in assessing the distribution of program resources to local government applicants.

Second, although at least one applicant in each of the 50 states received an award between 2003 and 2007, the receipt of awards varies widely among states. Figure 2 shows for each state both the number of awards won by city and town governments - the geographic scale at which we analyze award patterns-and the total amount won by these entities. ${ }^{9}$ The darker shading in the figure depicts states with a greater number of winning applications. Not surprisingly, these generally comprise older industrial states. Of the top 10 states, each receiving at least 45 awards, only California and Washington lie outside the Eastern and Midwestern parts of the country. The graduate circles in Figure 2 represent the total dollar amount of support awarded over this period. Nine of the 10 states with the highest 


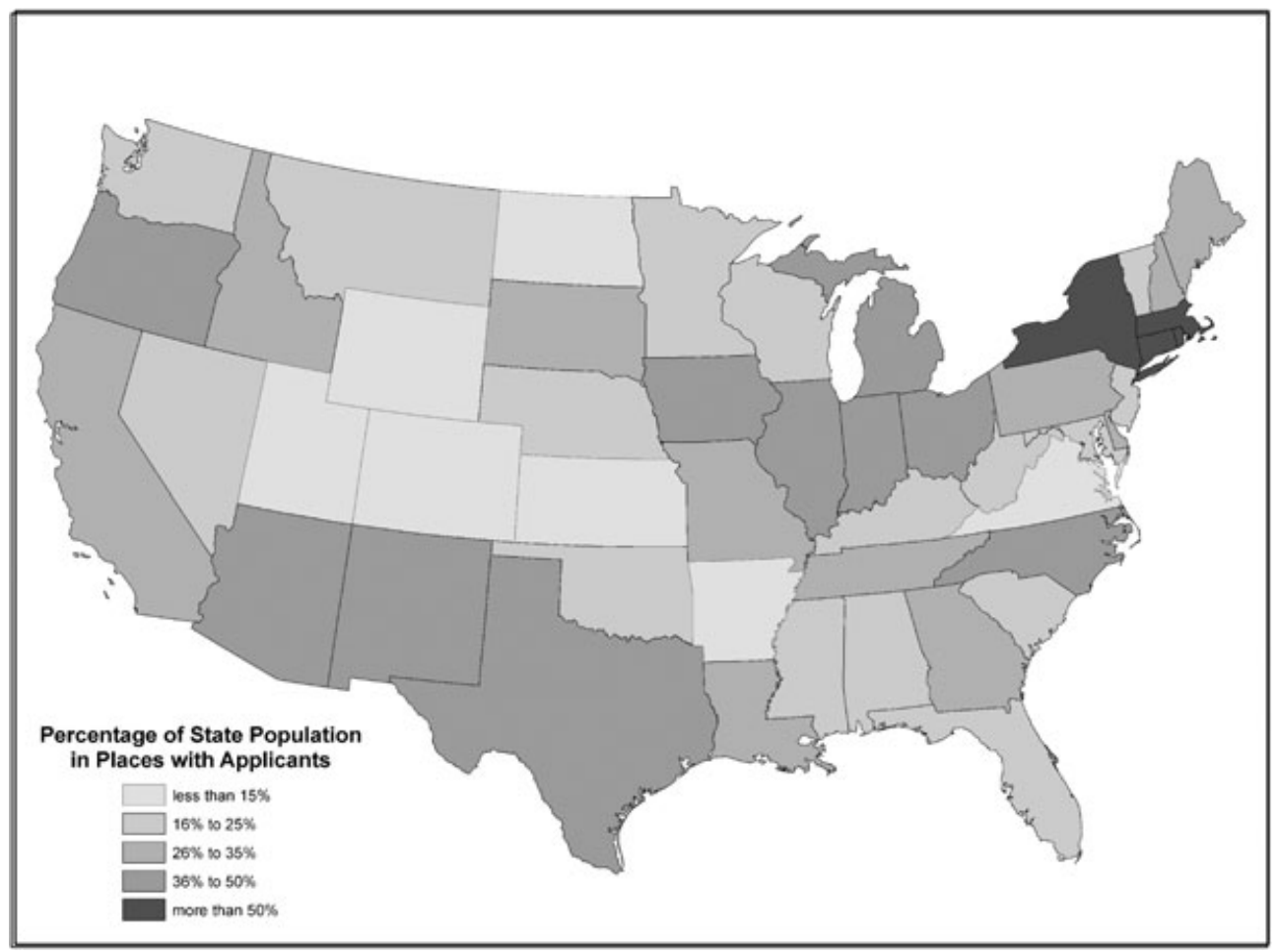

Figure 3. EPA Brownfields Award Applicants, as Percentage of State Population (2003-2009).

dollar amount of awards also lie in the East and Midwest, with California the only exception. It seems apparent from Figure 2 that industrial legacy-a proxy for environmental risk-influences program awards, yet this does not obviate the potential role of distributive politics.

Third, Figure 3 depicts the percentage of each state's total population that lived in places eligible to apply for brownfields support that actually did apply for grant support. Lighter shading in the figure indicates that a relatively low percentage of the state's population lived in places that applied for federal brownfields support. While most of the population of states such as Connecticut, Massachusetts, New York, and Rhode Island reside in applicant communities, less than 15 percent of the population of Arkansas, Colorado, Kansas, North Dakota, Utah, Virginia, and Wyoming can claim this. This is a consideration for our analysis. In assessing correlates of successful access, it is essential to consider not only the characteristics of successful and nonsuccessful applicants, but also to examine nonapplicants. If the likelihood of places not applying for federal financial support correlates with one or more of the explanatory variables we discuss below-that is, nonapplicants are not "missing at random"-our model estimates of the relationships between winning awards and community characteristic will be biased (Allison, 2001). This "selection effect" is a recognized feature of competitive grant programs (Collins \& Gerber, 2006, 2008). In the analysis described here, we employ a Heckman model to correct 
for this bias and analyze missing applicants against the explanatory variables in the model.

Our overall objective in performing this analysis is to test a set of expectations regarding the allocation of EPA Brownfields Program resources. The following section develops a series of hypotheses, followed by a section reports results of the analysis.

\section{Hypotheses and Variables}

Drawing on the robust empirical literature analyzing the interplay of public interest, distributive politics, and organizational capacity and process in the allocation of government program resources, this section develops six hypotheses organized around four sets of factors: (i) program priorities related to environmental remediation and economic development; (ii) applicant resources and civic capacity; (iii) state policies promoting brownfields redevelopment; and (iv) institutional and partisan distributional politics. ${ }^{10}$ Table 1 summarizes the independent variables used to test these hypotheses.

\section{Program Priorities}

The Brownfields Program was developed to promote both environmental remediation and economic development. As an extension of EPA's environmental mission, the Program exists to promote local action toward cleaning up and redeveloping contaminated properties. As a consequence:

Hypothesis 1: More contaminated land increases the likelihood of an EPA Brownfields award.

We model this expectation using Environmental Concerns, a count of records of environmental concerns in each county normalized by county population. These include contaminated as well as noncontaminated locations and come from an EPA database on sites and facilities of environmental interest to the Agency. ${ }^{11}$ Based on the above hypothesis, Environmental Concerns should be positively correlated with the likelihood of an EPA Brownfields award.

When initiated in 1995, EPA Brownfields pilots represented a departure from the political and environmental contentiousness of Superfund (Hird, 1994; Rahm, 1998). The pilot projects were contemporaneous with EPA's experimentation with a variety of voluntary and competitive policy instruments, with the goal of the brownfields pilot effort to support new approaches to remediation and redevelopment that were rooted in local initiative, local redevelopment decision making, and risk-based cleanup. In conjunction with environmental goals, the subsequent EPA Brownfields Program is designed to promote the redevelopment of economically distressed communities. Because this priority is connected to stated commitments related to environmental equity, we specify two related hypotheses.

Hypothesis 2a: Economic distress increases the likelihood of an EPA Brownfields award. 


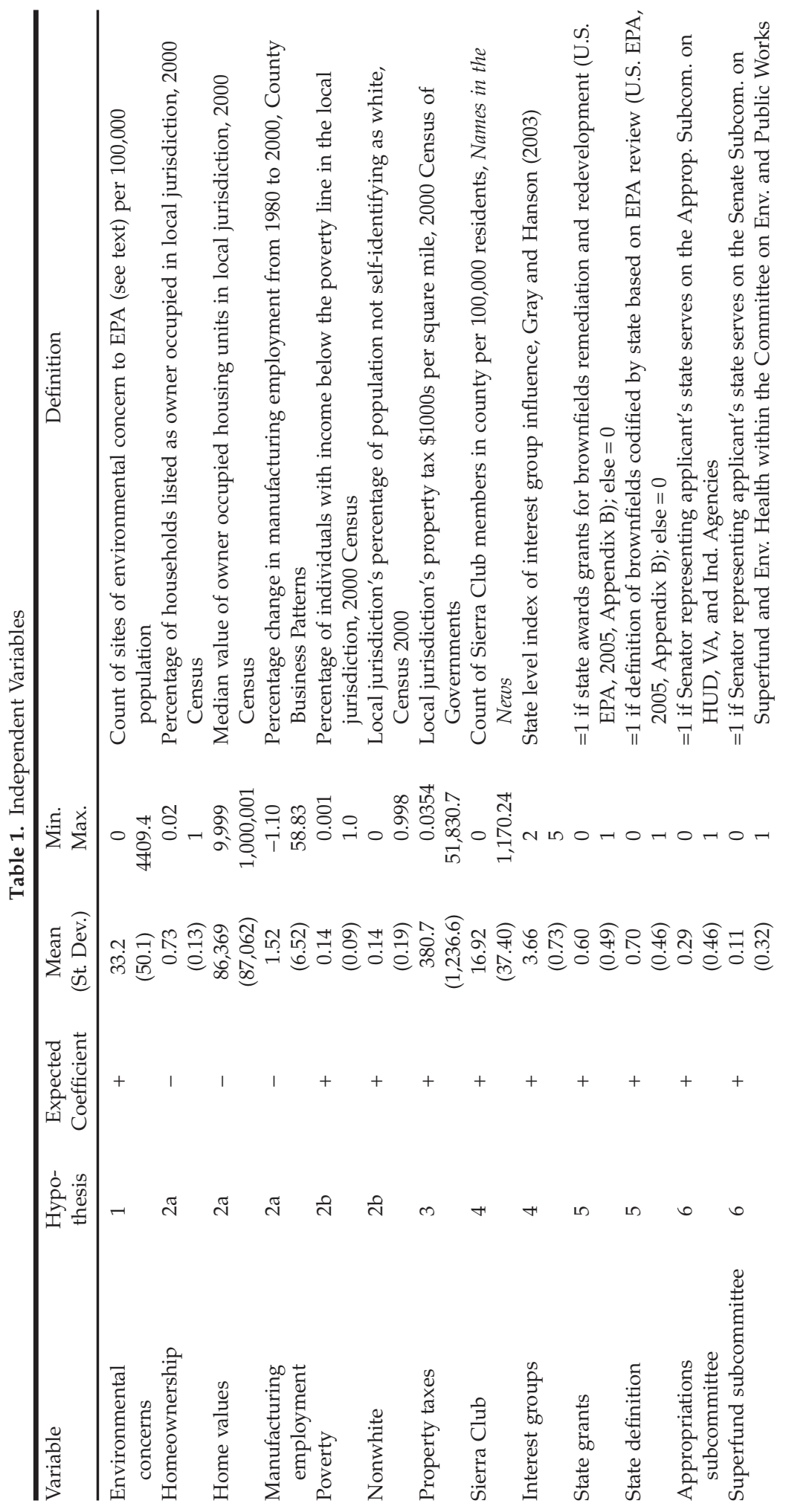




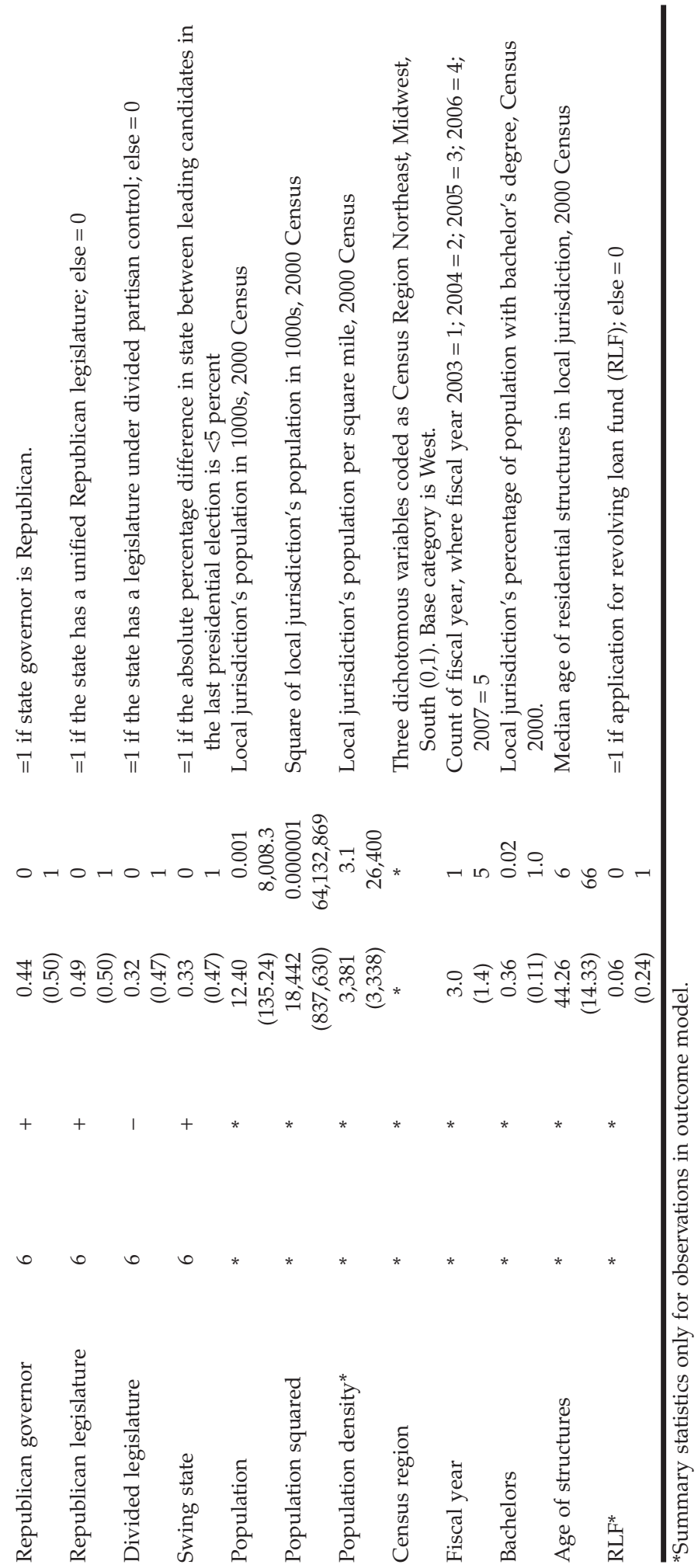


Three variables gauge the influence of economic distress. Homeownership and Home Values measure, respectively, the proportion of households listed as owner occupied and the median value of occupied homes in the applicant's local jurisdiction according to the 2000 Census. Manufacturing Employment uses data from County Business Patterns to calculate the percentage change in total manufacturing employment in each county between 1980 and 2000. Based on the objective of promoting the redevelopment of distressed communities, we would expect negative relationships between homeownership rates, home values, and change in manufacturing employment and the likelihood of winning an award.

Promoting development in distressed communities is also consistent with broader commitments to environmental equity embraced by EPA and other federal, state, and local environmental regulators over the last two decades. Research and advocacy highlighting the association of environmental hazards and concentrations of residents of color and low-income residents prompted the Clinton administration's EPA to undertake a series of initiatives designed to address these disparities, commitments also articulated by the Bush-appointed EPA Administrator (Johnson, 2008). ${ }^{12}$ The empirical scholarship linking these populations to environmental hazards remains contentious. In the most comprehensive study to date, Ringquist (2005) reports results from a meta-analysis of 49 environmental equity studies, concluding that environmental inequity-particularly related to residents of color-is a significant though small factor across studies. ${ }^{13}$ Nonetheless, EPA's explicit commitment to environmental justice should influence the distribution of Brownfields Program resources. Consistent with this expectation, previous research on the distribution of Brownfields Pilot awards before 2003 finds a strong positive correlation between nonwhite (Greenberg \& Hollander, 2006; Greenberg \& Issa, 2005) and low-income (Solitare \& Greenberg, 2002) populations and the distribution of Brownfields Program awards.

Hypothesis 2b: Concentrated nonwhite and low-income populations increase the likelihood of an EPA Brownfields award.

Two variables drawn from 2000 Census figures gauge the distribution of EPA Brownfields awards based on environmental equity. Nonwhite measures the proportion of the population that has not self-identified itself as only of white race. ${ }^{14}$ Poverty represents the proportion of individuals with income below the poverty line. We expect Nonwhite and Poverty to positively predict the likelihood of a Brownfields Program award.

\section{Government and Civic Capacity}

EPA Brownfields Program awards are modest relative to needs and successful applicants generally combine this support with other private, local, state, and federal sources, so better-resourced applicants presumably enjoy advantages in capital and personnel (U.S. Government Accountability Office, 2005). More robust local government resources, therefore, should provide greater opportunities to pursue and take 
advantage of EPA Brownfields support. A variety of nonfinancial factors are also at play. A Brownfield award may serve as an important symbol of commitment or performance for agency administrators, politicians, and other local actors (Wernstedt et al., 2006). Responsiveness to these nonfinancial incentives may be greatest in well-resourced government agencies, where basic resource commitments are not immediately at risk. Hypothesis 3, therefore, predicts that local governments with greater resources are more likely to receive Brownfields Program awards.

Hypothesis 3: Other government resources increase the likelihood of an EPA Brownfields award.

Property Taxes measures total local government property taxes in each local government jurisdiction included in the 2000 Census of Governments, normalized by land area of the jurisdiction in order to capture the spatial extent of the government's service area. We expect this variable will positively influence the likelihood of a Brownfields Program award.

Given explicit program commitments to promoting community involvement, civic capacity also may play an important role.

\section{Hypothesis 4: Civic capacity increases the likelihood of an EPA Brownfields award.}

We employ three variables to gauge the influence of civic capacity. College Educated measures the percent of the population with a bachelor's degree or higher. Based on prior research on political engagement, we expect that communities with larger college-educated populations are more likely to receive awards (Martin, 2003). Sierra Club measures the count of Sierra Club membership in the applicant's county per 100,000 individuals and is based on data provided by San Francisco-based Names in the News. We anticipate that greater support for environmental concerns will increase the likelihood of local remediation efforts, so we expect Sierra Club should positively relate to the likelihood of an EPA Brownfields Program award. ${ }^{15}$ Finally, a long research tradition examines the role of interest group pressures on agency decision making. Recent empirical evidence likewise demonstrates interest group influence in environmental policy (Daley, 2007; Hird, 1994; Ringquist, 1994). Interest Groups is a measure of the number of groups registered to lobby before the state legislature developed by Gray and Lowery (1996), based here on 2002 data (Gray \& Hanson, 2003). We expect Interest Groups to positively correlate with the likelihood of an applicant receiving an award.

\section{State Policy}

The EPA Brownfields Program developed in conjunction with a variety of state and local initiatives promoting the redevelopment of brownfields. Some states have adopted their own legislation and developed funded brownfield and voluntary cleanup programs to promote brownfields reuse, thus providing an institutional context more conducive for all brownfield activities. 
Hypothesis 5: State policies promoting brownfields remediation increase the likelihood of an EPA Brownfields award.

Drawing on an EPA review of state-level brownfields and voluntary cleanup policies (U.S. Environmental Protection Agency, 2005), we employ State Definition as a dichotomous variable taking a value of 1 when the state has codified a definition of brownfields. State Grants also is a dichotomous variable taking a value of 1 when the EPA report identifies an existing state-level grant program focused on brownfields remediation and redevelopment. We expect that both will positively predict the likelihood of winning.

\section{Political Institutions}

Institutional politics and oversight also feature prominently in the broad and varied empirical research literature on agency policy administration. Agencies often are subject to the influence by multiple principals and interests (Aberbach \& Rockman, 2000; Waterman, Rouse, \& Wright, 1998; Whitford, 2005; Yackee, 2006); wield uncertain, sometimes competing policy mandates (Chun \& Rainey, 2005; Nicholson-Crotty, 2004); negotiate administrative procedures characterized by complex informational and legal contingencies (Carpenter, 2002; Potoski, 1999); and respond to diverse organizational and professional norms (Brehm \& Gates, 1997; Golden, 2000). Acknowledging the multidimensional nature of policy administration, empirical research consistently points to powerful political representation.

Hypothesis 6: Political representation increases the likelihood of an EPA Brownfields award.

We include in the model five dichotomous variables associated with institutional representation in Congress and partisan representation in Congress and state government. These vary over time. Superfund Subcommittee takes a value of 1 if either or both of the U.S. Senators from the applicant's state serve on the subcommittee that oversees the EPA Brownfields program (Senate Subcommittee on Superfund and Environmental Health within the Committee on Environment and Public Works) at the time of the award application. Appropriations Subcommittee similarly has a value of 1 if either or both of the U.S. Senators from the applicant's state serve on the Appropriations subcommittee that oversees EPA (Subcommittee on HUD, VA, and Independent Agencies). ${ }^{16}$ Both are expected to positively influence the likelihood that an applicant will receive a Brownfields award.

With respect to partisan representation, a Republican presidential administration governed throughout the period examined (2003 to 2007) and Republicans controlled Congress for the first four of those five years. If the Brownfields program is subject to distributive pressures tied to partisan affiliations, we should expect Republican partisan representation to be positively related and Democratic representation to be negatively related with the likelihood of an EPA Brownfields award. Republican Governor, a dichotomous variable, takes a value of 1 when the governor of the applicant's state is a Republican in the application year. Republican Legislature 
takes a value of 1 in states under unified Republican control of the state legislature, while Divided Legislature takes a value of 1 when the applicant's state legislature is under divided partisan control (these two dichotomous variables are evaluated in reference to the base category of a unified Democratic legislature). Republican Governor and Republican Legislature are expected to yield positive coefficients, while Divided Legislature is expected to yield a negative coefficient. ${ }^{17}$

Finally, Swing State is a dichotomous variable taking a value of 1 when the state vote totals of the Democratic and Republican presidential candidates in the preceding presidential election differ by five or fewer percentage points, drawn from the Statistical Abstract of the United States. A strong anecdotal and journalistic tradition supports the expectation that states expected to be competitive in future presidential elections disproportionately benefit from federal government resources. As a consequence, with the expectation that the allocation of resources under this program will exhibit the distribution of resources toward competitive states, we expect that Swing State will generate a positive coefficient.

\section{Control Variables}

We include control variables associated with a handful of potentially confounding factors. First, controlling for the number of residents in each jurisdiction, Population measures the total population of the local jurisdiction based on the 2000 Census, while Population Squared is this value squared (to account for a possible nonlinear effect of population). Both appear in the selection stage, but are omitted from the outcome stage of the model. Population Density represents the number of residents per square mile and appears in the outcome model.

Second, to control for possible regional differences we include three dichotomous variables for the Northeast, Midwest, and South census regions. In the model, these are categorical shift variables with the base category, where all these three regional variables take a value of 0 , indicating localities in the Western census region.

Third, we include three additional variables to control for socio economic characteristics of the local jurisdictions and characteristics of the application. Age of Structures represents the median age of residential structures according to the 2000 Census. Fiscal Year captures the year of the grant or loan application and RLF is a dichotomous variable representing whether the applicant is applying for support for a revolving loan fund. RLF is important to distinguish since not only is it a loan, rather than a grant, but the average value of revolving loan awards are more than five times those of cleanup and assessment grants.

\section{Model and Results}

We employ a full maximum likelihood Heckman probit model with HuberWhite robust standard errors to examine the correlates of EPA Brownfields Program applicants and award winners. The traditional Heckman technique is estimated in two stages: first a selection equation estimating a dichotomous variable equaling 1 if an action is observed and 0 otherwise, and second an outcome equation predicting 
Table 2. EPA Brownfields Applicants and Awards Local Governments, 2003-2007

\begin{tabular}{|c|c|c|}
\hline Variable & Applicant Coefficient (SE) & Award Coefficient (SE) \\
\hline Environmental concerns & $0.003(0.001)^{* *}$ & $0.004(0.002)^{*}$ \\
\hline Homeownership & $-2.437(0.122)^{* *}$ & $0.039(0.475)$ \\
\hline Home values & $-1.41 \mathrm{e}-06(3.90 \mathrm{e}-07)^{* *}$ & $-6.06 \mathrm{e}-07(1.05 \mathrm{e}-06)$ \\
\hline Manufacturing employment & $-0.010(0.003)^{* *}$ & $0.013(0.008)^{*}$ \\
\hline Poverty & $-0.718(0.211)^{* *}$ & $-1.519(0.865)^{*}$ \\
\hline Nonwhite & $0.982(0.088)^{* *}$ & $-0.451(0.240)^{*}$ \\
\hline College educated & $1.590(0.256)^{* *}$ & $0.195(0.814)$ \\
\hline Property taxes & $1.76 \mathrm{e}-05(6.23 \mathrm{e}-06)^{* *}$ & $5.11 \mathrm{e}-05(1.39 \mathrm{e}-05)^{* *}$ \\
\hline Interest groups & $-0.005(0.032)$ & $-0.036(0.059)$ \\
\hline Sierra Club & $-0.002(0.001)^{* *}$ & $-0.002(0.003)$ \\
\hline State grants & $-0.072(0.036)^{*}$ & $-0.102(0.092)$ \\
\hline State definition & $-0.010(0.041)$ & $-0.068(0.085)$ \\
\hline Appropriations subcommittee & $0.020(0.047)$ & $0.143(0.089)$ \\
\hline Superfund subcommittee & $-0.211(0.064)^{* *}$ & $0.401(0.102)^{* *}$ \\
\hline Republican governor & $0.024(0.034)$ & $-0.134(0.072)^{*}$ \\
\hline Republican legislature & $-0.369(0.048)^{* *}$ & $0.230(0.102)^{*}$ \\
\hline Divided legislature & $-0.663(0.050)^{* *}$ & $0.215(0.109)^{*}$ \\
\hline Swing state & $-0.089(0.042)^{*}$ & $-0.069(0.096)$ \\
\hline Population density & & $-5.11 \mathrm{e}-05(1.59 \mathrm{e}-05)^{* *}$ \\
\hline Population $(\times 1000)$ & $0.002(0.000)^{* *}$ & \\
\hline Population-squared & $-2.75 \mathrm{E}-07(3.14 \mathrm{e}-08)^{* *}$ & \\
\hline Northeast region & $0.113(0.083)$ & $-0.146(0.159)$ \\
\hline Midwest region & $0.396(0.072)^{* *}$ & $-0.251(0.131)^{*}$ \\
\hline Southern region & $-0.269(0.070)^{* *}$ & $0.033(0.142)$ \\
\hline Prior applicant & $1.381(0.042)^{*}$ & $0.046(0.143)$ \\
\hline Fiscal year & $-0.205(0.012)^{* *}$ & $0.165(0.029)^{* *}$ \\
\hline Age of structures & $0.003(0.001)^{*}$ & $0.010(0.004)$ \\
\hline RLF & & $-0.315(0.123)^{*}$ \\
\hline Constant & $0.044(0.193)$ & $-0.195(0.514)$ \\
\hline Rho & \multicolumn{2}{|c|}{$-0.394(0.097)$} \\
\hline Wald $\chi^{2}$ (Model) & \multicolumn{2}{|c|}{$199.98 * *$} \\
\hline Wald $\chi^{2}$ (Independent Eqs.) & \multicolumn{2}{|c|}{$12.36^{* *}$} \\
\hline Observations & 54,802 & 1,864 \\
\hline
\end{tabular}

Maximum likelihood Heckman probit estimates. Coefficients are selection stage (left column) estimating the likelihood of an application and outcome stage (right column) estimating likelihood an application yields an award. Robust standard errors reported in parentheses. ${ }^{*} 0.10,{ }^{* *} 0.01$.

the model's dependent variable. ${ }^{18}$ In our case, the outcome dependent variable is also dichotomous, equaling 1 if the applicant won a Brownfields Program award and 0 otherwise. The model generates two sets of coefficients, a selection equation predicting applicants and an outcome or equation predicting awards. Table 2 presents the results of the exercise, reporting estimates in the selection or Applicant stage in the left column and the outcome or Award on the right. We begin by interpreting Award stage estimates associated with the article's six hypotheses, then briefly review estimates for the Applicant stage and control variables, which yield some additional useful information.

Consistent with Hypothesis 1, the variable measuring environmental sites of interest, Environmental Concerns, is significant and positive. Though, as noted, some caution is in order when drawing inferences from such a proxy, these findings 


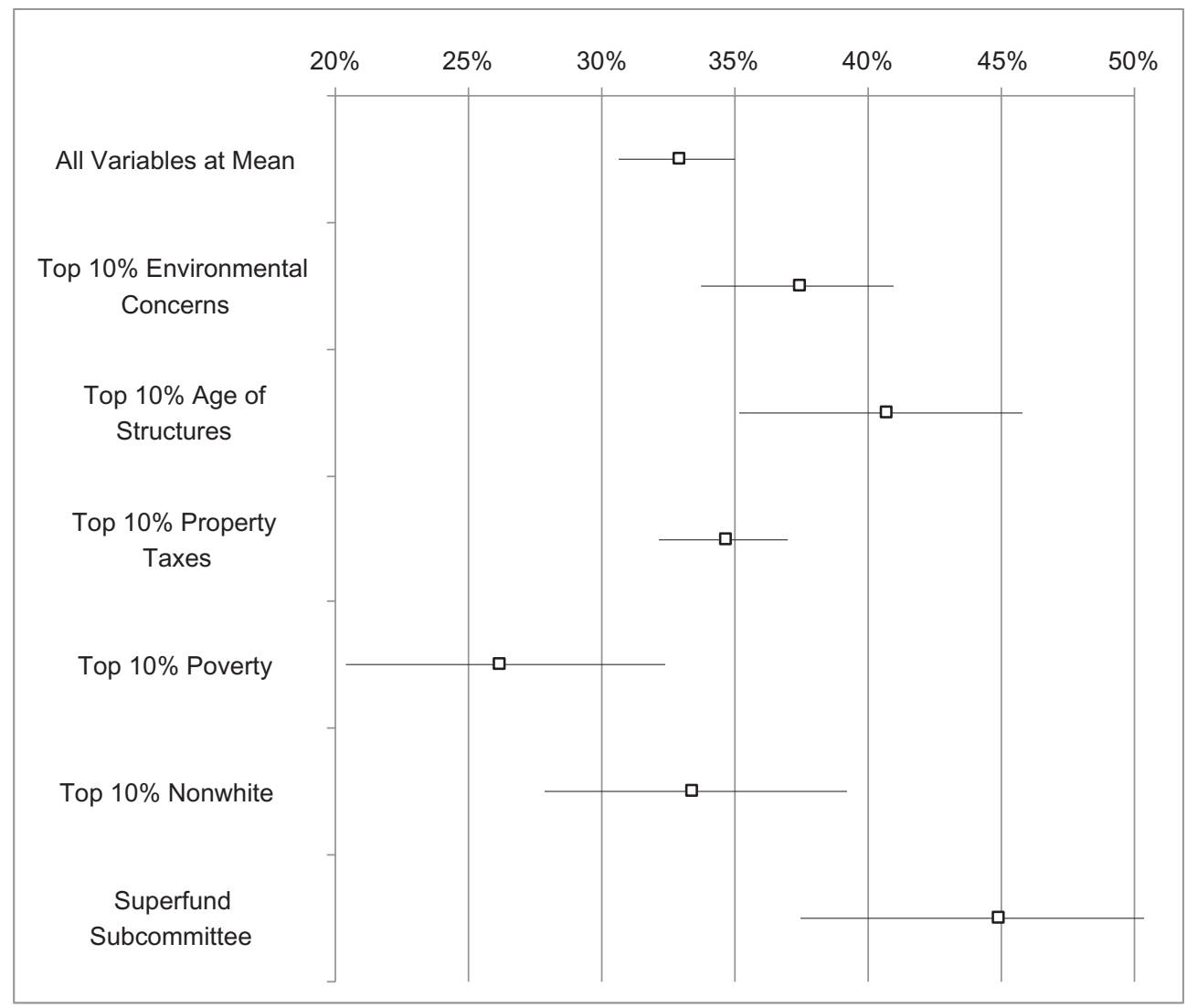

Figure 4. Predicted Probability Applicant Receives an EPA Brownfields Program Award, Depicted with 95 Percent Confidence Intervals.

suggest the allocation of EPA Brownfields resources is consistent with explicit program objectives by targeting communities in counties where a large number of sites of environmental concern per capita evince environmental risk.

Figure 4, depicting substantive interpretations for a handful of statistically significant variables, illustrates the impact of this environmental variable. ${ }^{19}$ Applicant communities in counties in the top decile of Environmental Concerns (>54.2 sites per 100,000 residents) have a 37 percent likelihood of winning an award, holding all other variables at their means, compared with a 33 percent likelihood of winning an award when all independent variables in the model are set at their mean values.

Measures of economic distress lend no support for Hypothesis 2a. Two of the three variables, Homeownership and Home Values, are not statistically significant and thus provide no evidence to support distribution of EPA Brownfields Program awards to economically distressed localities. Manufacturing Employment produces an estimate contrary to expectations, generating marginally significant positive coefficients. In other words, higher rates of manufacturing employment growth are positively correlated with the likelihood of winning a Brownfields Program award. 
Hypothesis $2 \mathrm{~b}$ finds similarly little support. Both Poverty and Nonwhite produce significant and negative coefficients; that is, counter to our environmental equity hypothesis, applicants from localities with higher concentrations of poverty and higher concentrations of self-identified nonwhites are less likely to receive an EPA Brownfields award. Keeping in mind the variety of challenges measuring and modeling the between-race- and class-based inequities - and the relatively large city- or town-wide scale of our analysis-the robustness of our finding across different specifications highlights concerns about equity in the distribution of resources under the competitive EPA Brownfields Program.

For example, Figure 4 shows that applicant communities with 26 percent or more of their residents in poverty-the top decile of the Poverty variable for applicant communities-have a notably lower probability of winning an award (26 percent likelihood vs. 33 percent likelihood when all independent variables are set at their mean values). Applicant communities where nonwhites constitute more than 61 percent of the population - the top decile of our Nonwhite variable-had a nearly identical likelihood of winning awards as when all variables are set at their mean.

Consistent with Hypothesis 3, the model results suggest well-resourced local governments are more likely to win support, other factors being equal. Property Taxes, measuring each local jurisdiction's property tax collection per unit area, generates positive and significant coefficients as expected. Figure 4 also shows this, where the top decile of Property Taxes - communities where property taxes exceed \$3 million/square mile-have a 35 percent likelihood of winning an award vs. 33 percent in communities where all variables are set at their means.

The civic engagement variables associated with Hypothesis 4 do not perform well. All three variables Interest Group, Sierra Club, and College Educated fall well short of significance. To some degree this may reflect limitations of the variables. Interest Group is observed at the state level, omitting important within-state variance, while Sierra $\mathrm{Club}$ is observed at the county level, omitting potentially important variation at the local level. Sierra Club is also a blunt proxy insofar as national nonprofit environmental organizations typically have not played major roles in either the economic or environmental dimensions of brownfields since passage of the 2002 national legislation.

The results also do not support Hypothesis 5, which holds that applicants from states with brownfields policies are more likely to be successful EPA Brownfields applicants. Neither State Definition nor State Grants yield statistically significant coefficients. A more developed state program, which has explicitly codified the brownfields concept and offers state-level brownfields grants, appears no more likely to attract EPA Brownfields Program support.

Finally, the political variables yield mixed support for Hypothesis 6. Superfund Subcommittee is positive and significant, as expected; that is, if an applicant community is located in a state where one or both of its Senators sit on the Superfund Subcommittee (dummy variable set equal to 1), the community has a higher likelihood of winning an award. As depicted in Figure 4, when Superfund Subcommittee equals 1 and all other variables equal their mean values the probability of winning is nearly 45 percent. The Appropriations Subcommittee dummy variable falls just short of statistical significance. 
The variables based on state-level partisan control yield inconsistent results. Republican Governor is unexpectedly negative and significant, while both Republican Legislature and Divided Legislature are puzzlingly positive in the award stage. Unified state legislatures in Republican hands and those under divided partisan control were both more likely to win compared to a legislature controlled by Democrats, the reference category; but also both were less likely to apply. Swing State also yields inconsistent results. A dichotomous variable taking a value of 1 when the margin at the state-level vote totals between the Democratic and Republican presidential candidates in the previous election was less than 5 percentage points, this variable yields small negative coefficients. Contrary to the common wisdom, at least in our analysis, electorally competitive states are actually less likely to benefit from the distribution of resources under the EPA Brownfields program.

The model yields a handful of additional informative results. In part because of the large number of observations, most of the variables in the model's Applicant stage are significant, a handful of which are intriguing. Among the measures of economic distress, Manufacturing Employment and Home Ownership are both negative and significant as expected. Indicators of environmental equity Poverty and Nonwhite are negative and significant, contrary to expectations.

Consistent with stated program aims targeting economically distressed communities, those communities with higher rates of home ownership are less likely to apply and less likely to receive program support. Contrary to program objectives related to equity, however, communities with high rates of poverty are both less likely to apply for and less likely to receive EPA Brownfields support. The civic capacity variables College Educated, which is marginal in the Award stage, is positive and significant in the Applicant stage. Places with larger concentrations of college educated adults are more likely to apply for EPA Brownfields support, thus providing at least a modicum of support for Hypothesis 5. By contrast, Interest Group falls short of significance and Sierra Club is significant and negative, contrary to our expectations.

Among the control variables in the Applicant stage, Population is positive and significant, indicating that local jurisdictions with more residents are more likely to apply for awards. Population Squared is also significant but with a negative sign, suggesting that the greater likelihood flattens out higher population levels. Population Density is negative and significant at the Award stage, implying that jurisdictions with high population densities are less likely to receive awards than those with lower densities. Also in the outcome model, our Fiscal Year control variable is positive and highly significant, indicating that the likelihood of winning increased over the 20032007 period.

\section{Conclusion}

The EPA Brownfields Program promotes local public and private efforts to clean up and reuse hundreds of thousands of properties contaminated by past activities at factories, transportation facilities, commercial businesses, and myriad other uses in cities, towns, and rural areas across the United States. Working in conjunction with a variety of state and local initiatives, the Brownfields Program exemplifies more 
cooperative approaches to encourage voluntary environmental improvements, an increasingly prominent alternative to traditional regulatory models of environmental protection. Yet, empirical evidence validating the success of voluntary approaches such as the Brownfields Program is by no means settled (Dietz \& Stern, 2003; Greenberg \& Issa, 2005; Rivera, deLeon, \& Koerber, 2006). Both the efficacy of these programs in balancing environmental and economic concerns and the appropriate mix of such factors as regulatory pressure, incentives, information provision, and public involvement (Wernstedt, 2001) remain uncertain.

Our analysis of the distribution of EPA Brownfields Program awards between 2003 and 2007 indicates that, as expected, communities with well-resourced public sectors and powerful institutional and partisan representation appear more likely to receive Brownfields Program support. The pattern of allocating program resources preferentially to localities with more sites of environmental concern is also not surprising, since it evinces an explicit program commitment. However, the targeting of the socio economic objectives of the Brownfields Program is less convincing. While our results indicate that, as expected, localities that have lost manufacturing jobs since 1980 are more likely to apply to the EPA Brownfields Program, they appear less likely to actually receive program support. Similarly, contrary to explicit program commitments regarding environmental equity, applicants from localities with significant concentrations of individuals below poverty and individuals not self-identifying as white appear significantly less likely to win an EPA Brownfields Program award. These apparent mismatches not only run counter to program goals, but they also contravene previous analyses of EPA Pilot Program awards between 1995 and 2002 (Greenberg \& Hollander, 2006; Greenberg \& Issa, 2005; Solitare \& Greenberg, 2002). This in part may reflect the pilot nature of the earlier awards, which had no formal statutory base and disbursed much smaller award amounts. In addition, the apparent shift away from constituencies less supportive of Republican Party congressional majorities and Presidency after the 2002 codification of the Brownfields Program is consistent with a substantial body of existing scholarship on the allocation of both environmental risks and resources (Hird, 1994; Regens \& Rycroft, 1986) and federal project grants generally (Arnold, 1981).

The quantitative analysis presented in this article was motivated by the belief that theoretically informed empirical research contributes both to a fuller understanding of the consequences of policies and policy designs, as well as to developing scholarship on the institutional politics of agency program administration. We have acknowledged a range of limitations on available data and potentially confounding factors that our model's specification does not fully exhaust, making it important to exercise caution in drawing inferences from our analysis. Moreover, our empirical research examining the distribution of program research cannot tell us about program consequences or outcomes, nor can it answer more fundamental questions about values implicit in policy design and implementation. However, the study described here, like the broader field of policy research, plays an important role in extending shared knowledge about the dynamics governing new and developing approaches to public policy design and implementation. 
Matthew Dull is an assistant professor in the Center for Public Administration and Policy at Virginia Tech.

Kris Wernstedt is an associate professor of Urban Affairs and Planning at Virginia Tech.

\section{Notes}

1. No national roster of brownfield sites exists, and information on their characteristics is spotty. Estimates of the total number of brownfields nationwide range from hundreds of thousands to a million sites, while estimates of average site size run from under one-half acre to 10 acres. They exist in older and newer urban areas, as well as suburban and rural locations. Previous activities generating brownfields include industry, commercial, and residential uses (Heberle \& Wernstedt, 2006).

2. See Salamon (2002) for a general overview of policy "tools."

3. Greenberg and Issa (2005) provide a useful summary of early EPA brownfields pilot initiatives.

4. Of this authorized amount, \$200 million were allocated to site cleanup and assessment grant and loan programs and $\$ 50$ million to state and tribal response programs.

5. Despite their roots in environmental protection, Meyer (2000) concludes voluntary cleanup programs serve as de facto local economic development programs. Likewise, a recent study of Colorado's Voluntary Cleanup Program finds evidence that liability relief attracts program participation to sites with relatively minor contamination, suggesting that these sites may enter the program principally to boost economic development (Alberini, 2007). A broader research literature subjects the balance of priorities in voluntary environmental policies more generally to empirical scrutiny (Darnall \& Sides, 2008; Rivera \& deLeon, 2004; Rivera, deLeon, \& Koerber, 2006).

6. This account echoes the regulatory reform logic of "democracy by disclosure" (Graham, 2002), which holds that enhanced transparency improves regulatory governance. However, like many other policy areas the capacity of policymakers to discern whether remediation programs effectively promote social values may limit the design of brownfields program in this respect.

7. Other brownfields research examines subjects as diverse as the influence of contamination on buyer and seller transactions (Boyd, Harrington, \& Macauley, 1996), correlates of successful redevelopments (Lange \& McNeil, 2004a, 2004b), public health issues (Pendergrass, 1999), environmental justice (Rowan \& Fridgen, 2003), community preferences (Greenberg \& Lewis, 2000), employment effects (Howland, 2007), green space conversions (Siikamäki \& Wernstedt, 2008), and the effect of contamination on the probability of redevelopment (McGrath, 2000).

8. This figure has remained relatively constant since 2003 , the first year of the competitive program after the 2002 federal legislation. In that first year, however, a surge of interest in the new program brought more than 1,300 applications for grants and loans. As a consequence, during the 2003 award cycle, only 16 percent of applicants received awards. Among the more than 400 cleanup grant applications in that year only 10 percent received support. In contrast, from 2004-2007, nearly 40 percent of applicants won awards.

9. To capture the characteristics of city and town governments, our analysis utilizes census data for "places," a U.S. Bureau of the Census designation that includes legally incorporated entities with local government functions.

10. In political science, a variety of formal economic theories analyze delegation and bureaucratic control through lenses of ideology (Epstein \& O'Halloran, 1999), partisan control (Kiewiet \& McCubbins, 1991), institutional capacity (Huber \& Shipan, 2002), and institutional choice (Moe, 1994, 2005). The focus of robust scholarly debate and a keen sense of scientific progress, parsimonious theories of agency behavior are often confounded by the complexity and fragmentation of program implementation (Carpenter, 2002; Spence, 1997; Woolley, 1993). Nonetheless, their assumptions have inspired and helped to frame much of the empirical work we build on here.

11. The EPA database includes Superfund sites, facilities subject to regulation under the Resource Conservation and Recovery Act, permits under the National Pollutant Discharge Elimination System, and facilities reporting to the Toxic Release Inventory System, among others (see http:/ /www.epa.gov/ enviro/geo_data.html, accessed 15 June 2009, for a description). This database constitutes an admit- 
tedly problematic proxy for contamination since it includes a wide range of operating facilities with environmental permits, in addition to several types of contaminated sites. However, it is one of only three national level databases of contaminated or potentially contaminated properties, the other two being the National Priorities List (which contains sites eligible for Superfund program support) and the Comprehensive Environmental Response, Compensation, and Liability Information System (CERCLIS) list of sites nominally under investigation by EPA for potential contamination. The Superfund list contains only roughly 1,250 sites currently and it is too limited for our purposes, while the CERCLIS list of 12,000 active and another 35,000 archived sites is inconsistent and includes many sites that lack environmental issues.

12. Steps taken by the Clinton administration to address environmental equity include the creation of EPA's Office of Environmental Justice (formerly the Office of Environmental Equity) in 1992; the National Environmental Justice Advisory Council established in 1993 to promote dialogue between EPA and community, local government, academic, and nongovernment stakeholders regarding environmental justice; and Clinton Executive Order 42 USC 4321 mandating federal agencies place new emphasis on environmental equity in program administration.

13. Among the studies challenging this link, for example, Atlas (2002) finds the allocation of hazardous waste management facilities is correlated with higher concentrations of people of color and lowincome populations, but this pattern is due largely to a small number of sites in high-density locations with majority populations of color. A significant difficulty in analyzing equity is that the level of spatial aggregation influences results. The variables we use in our place-level analysis do not avoid this problem.

14. The 2000 U.S. Census asked respondents to report the race or races they consider themselves to be. Our Nonwhite variable equals the total population of each place minus the number of residents that identified themselves as only white, expressed as a percentage of the total population. Nonwhite will not include those Hispanics who identified themselves only as white, while it will include those Hispanics who identified themselves as other than white (or as white and one or more other races).

15. Daley's (2007) analysis of state voluntary cleanup initiatives shows that environmental group membership, measured the same way, negatively predicts the likelihood of adoption. We have borrowed the variable; however, we expect that strong local support for environmental causes will enhance state and local attention toward environmental cleanup. The influence of civic capacity relates as well to the literature examining the central role of inter-organizational networks (Schneider, Scholz, Lubell, Mindruta, \& Edwardsen, 2003; Scholz \& Wang, 2006) in program administration.

16. We omit parallel indicators of committee representation in the House of Representatives since it is not practical in many situations to locate a brownfield applicant's projects in a single Congressional District.

17. Empirical research examining the impact of divided government on legislative productivity, financial performance, and other measures of governance in state governments is not without contention; nonetheless, both empirical and normative models of governance suggest divided partisan control is negatively correlated with government performance (Coleman, 1999; Krueger \& Walker, 2008; McAtee, Yackee, \& Lowery, 2003).

18. In the traditional Heckman model, the residuals produced by the first-stage estimates measured are included in the outcome equation as a new variable called the Inverse Mill's Ratio or Lambda (Heckman, 1979). The maximum-likelihood Heckman model estimates both stages simultaneously.

19. In an ordinary least squares regression, the effect of a marginal change in any given independent variable on the value of the dependent variable is constant across all values of the independent variable, but in the probit model the effect depends on the distribution of the values of all independent variables and their coefficients.

\section{References}

Aberbach, Joel D., and Bert A. Rockman. 2000. In the Web of Politics: Three Decades of the U.S. Federal Executive. Washington, DC: Brookings Institution Press.

Alberini, Anna. 2007. “Determinants and Effects on Property Values of Participation in Voluntary Cleanup Programs: The Case of Colorado." Contemporary Economic Policy 25 (3): 415-32.

Allison, Paul D. 2001. Missing Data. Thousand Oaks, CA: Sage Publications. 
Arnold, R. Douglas. 1981. “The Local Roots of Domestic Policy.” In The New Congress, ed. T. E. Mann, and N. J. Ornstein. Washington, DC: American Enterprise Institute, 250-87.

Atlas, Mark. 2002. "There Goes the Neighborhood: Environmental Equity and the Location of New Hazardous Waste Management Facilities." Policy Studies Journal 30 (2): 171-92.

Beam, David R., and Timothy J. Conlan. 2002. "Grants." In The Tools of Government: A Guide to the New Governance, ed. Lester M. Salamon. New York: Oxford University Press, 340-80.

Boyd, James, Winston Harrington, and Molly Macauley. 1996. “The Effects of Environmental Liability on Industrial Real Estate Development." Journal of Real Estate Finance and Economics 12 (1): 37-58.

Brehm, John, and Scott Gates. 1997. Working, Shirking, and Sabotage: Bureaucratic Response to a Democratic Public. Ann Arbor: University of Michigan Press.

Carpenter, Daniel. 2002. "Groups, the Media, Agency Waiting Costs and FDA Drug Approval." American Journal of Political Science 46 (3): 490-505.

Chun, Young Han, and Hal G. Rainey. 2005. "Goal Ambiguity and Organizational Performance in U.S. Federal Agencies." Journal of Public Administration Research and Theory 15 (4): 529-57.

Coleman, John J. 1999. "Unified Government, Divided Government, and Party Responsiveness." American Political Science Review 93 (4): 821-35.

Collins, Brian K., and Brian J. Gerber. 2006. "Redistributive Policy and Devolution: Is State Administration a Road Block (Grant) to Equitable Access to Federal Funds?" Journal of Public Administration Research $\mathcal{E}$ Theory 16 (4): 613-32.

- 2008. "Taken for Granted? Managing for Social Equity in Grant Programs." Public Administration Review 68 (6): 1128-41.

Council for Urban Economic Development. 1999. Brownfields Redevelopment: Performance Evaluation. Washington, DC: Author.

Daley, Dorothy M. 2007. "Voluntary Approaches to Environmental Problems: Exploring the Rise of Nontraditional Public Policy." Policy Studies Journal 35 (2): 165-80.

Daley, Dorothy M., and David F. Layton. 2004. "Policy Implementation and the Environmental Protection Agency: What Factors Influence Remediation at Superfund Sites?" 32 (3): 375-92.

Dana, David A. 2005. "State Brownfields Programs as Laboratories for Democracy." NYU Environmental Law Journal 14 (1): 86-107.

Darnall, Nicole, and Steven Sides. 2008. "Assessing the Performance of Voluntary Environmental Programs: Does Certification Matter?" Policy Studies Journal 36 (1): 95-117.

Dietz, Thomas, and Paul C. Stern, eds. 2003. New Tools for Environmental Protection: Education, Information, and Voluntary Measures. Washington, DC: National Academy Press.

Epstein, David, and Sharyn O'Halloran. 1999. Delegating Powers: A Transaction Cost Politics Approach to Policy Making under Separate Powers. Cambridge: Cambridge University Press.

Fortney, Matthew D. 2006. "Devolving Control over Mildly Contaminated Property: The Local Cleanup Program." Northwestern University Law Review 100 (4): 1863-906.

Golden, Marissa Martino. 2000. What Motivates Bureaucrats? Politics and Administration during the Reagan Years. New York: Columbia University Press.

Graham, Mary. 2002. Democracy by Disclosure: The Rise of Technopopulism. Washington, DC: Governance Institute/Brookings Institution Press.

Gray, Virginia, and David Lowery. 1996. The Population Ecology of Interest Representation: Lobbying Communities in the American States. Ann Arbor: University of Michigan Press.

Gray, Virginia, and Russell L. Hanson. 2003. Politics in the American States: A Comparative Analysis. Washington, DC: CQ Press.

Greenberg, Michael, and Justin Hollander. 2006. “The EPA's Brownfield Pilot Program as a Worthwhile Federalist Environmental Innovation." American Journal of Public Health 96 (2): 277-81.

Greenberg, Michael R., and Lori Issa. 2005. "Measuring the Success of the Federal Government's Brownfields Program." Remediation 15 (3): 83-94.

Greenberg, Michael, and M. Jane Lewis. 2000. “Brownfields Redevelopment, Preferences and Public Involvement: A Case Study of an Ethnically Mixed Neighborhood." Urban Studies 37 (13): 2501-14. 
Hamilton, James T., and W. Kip Viscusi. 1999. Calculating Risks: The Spatial and Political Dimensions of Hazardous Waste Policy. Cambridge, MA: MIT Press.

Heberle, Lauren, and Kris Wernstedt. 2006. "Understanding Brownfields Regeneration in the U.S. Local." Environment 11 (5): 479-97.

Heckman, J. J. 1979. “Sample Selection Bias as a Specification Error." Econometrica 47 (1): 153-61.

Hird, John A. 1994. Superfund: The Political Economy of Environmental Risk. Baltimore, MD: The Johns Hopkins University Press.

Howland, Marie. 2007. "Employment Effects of Brownfield Redevelopment: What Do We Know from the Literature?" Journal of Planning Literature 22 (2): 91-107.

Huber, John D., and Charles R. Shipan. 2002. Deliberate Discretion? The Institutional Foundations of Bureaucratic Autonomy. Cambridge: Cambridge University Press.

Hula, Richard C. 2001. "Changing Priorities and Programs in Toxic Waste Policy: The Emergence of Economic Development as a Policy Goal." Economic Development Quarterly 15 (2): 181-99.

Johnson, Stephen. 2008. Strengthening EPA's Environmental Justice Program (Memorandum). http:/ /www. epa.gov/compliance/resources/policies/ej/admin-ej-strength-memo-060908.pdf. Accessed December 21, 2009.

Kiewiet, D. Roderick, and Matthew D. McCubbins. 1991. The Logic of Delegation: Congressional Parties and the Appropriations Process. Chicago: University of Chicago Press.

Krueger, Skip, and Robert W. Walker. 2008. "Divided Government, Political Turnover, and State Bond Ratings." Public Finance Review 36 (3): 259-86.

Lange, Deborah, and Sue McNeil. 2004a. "Clean It and They Will Come? Defining Successful Brownfield Development." Journal of Urban Planning and Development 130 (2): 101-8.

2004b. "Brownfield Development: Tools for Stewardship." Journal of Urban Planning and Development 130 (2): 109-16.

Lyon, Thomas P., and John W. Maxwell. 2004. Corporate Environmentalism and Public Policy. Cambridge: Cambridge University Press.

Martin, Paul S. 2003. "Voting's Rewards: Voter Turnout, Attentive Publics, and Congressional Allocation of Federal Money." American Journal of Political Science 47 (1): 110-27.

Mazmanian, Daniel, and David Morell. 1992. Beyond Superfailure: America's Toxics Policy for the 1990s. Boulder, CO: Westview Press.

McAtee, Andrea, Susan Webb Yackee, and David Lowery. 2003. "Reexamining the Dynamic Model of Divided Partisan Government." The Journal of Politics 65 (2): 477-90.

McGrath, Daniel T. 2000. "Urban Industrial Land Redevelopment and Contaminated Risk." Journal of Urban Economics 47 (3): 414-42.

Meyer, Peter. 2000. Looking at State Voluntary Cleanup Programs in Perspective: Liability Relief, Flexible Cleanup Standards and Institutional Controls as Forms of Economic Development Subsidies. Louisville, KY: University of Louisville.

Moe, Terry M. 1994. "Integrating Politics and Organizations: Positive Theory and Public Administration." Journal of Public Administration Research and Theory 4 (1): 17-25.

- 2005. "Political Control and the Power of the Agent." Journal of Law, Economics E Organization 22 (1): 1-29.

Nakamura, Robert T., and Thomas W. Church. 2003. Taming Regulation: Superfund and Challenge of Regulatory Reform. Washington, DC: Brookings Institution.

Nicholson-Crotty, Sean. 2004. "Goal Conflict and Fund Diversion in Federal Grants to the States." American Journal of Political Science 48 (1): 109-21.

Pendergrass, John. 1999. "Sustainable Redevelopment of Brownfields: Using Institutional Controls to Protect Public Health." ELR News and Analysis 29 (5): 10243-58.

Potoski, Matthew. 1999. “Managing Uncertainty through Bureaucratic Design: Administrative Procedures and State Air Pollution Control Agencies." Journal of Public Administration Research and Theory 9 (4): 623-39. 
Rahm, Dianne. 1998. “Controversial Cleanup: Superfund and Implementation of U.S. Hazardous Waste Policy." Policy Studies Journal 26 (4): 719-34.

Regens, James L., and Robert W. Rycroft. 1986. "Measuring Equity in Regulatory Policy Implementation." Public Administration Review 46 (5): 423-31.

Ringquist, Evan. 1994. "Policy Influence and Policy Responsiveness in State Pollution Control." Policy Studies Journal 22 (1): 25-43.

. 2005. "Assessing Evidence of Environmental Inequities: A Meta-Analysis." Journal of Policy Analysis and Management 24 (2): 223-47.

Rivera, Jorge, and Peter deLeon. 2004. "Is Greener Whiter? The Sustainable Slopes Program and the Voluntary Environmental Performance of Western Ski Areas." Policy Studies Journal 32 (3): 417-37.

Rivera, Jorge, Peter deLeon, and Charles Koerber. 2006. "Is Greener Whiter Yet? The Sustainable Slopes Program After Five Years." Policy Studies Journal 34 (2): 195-221.

Rowan, George, and Cynthia Fridgen. 2003. "Brownfields and Environmental Justice: The Threats and Challenges of Contamination." Environmental Practice 5 (1): 58-61.

Salamon, Lester M., ed. 2002. The Tools of Government: A Guide to the New Governance. New York: Oxford University Press.

Schneider, Mark, John Scholz, Mark Lubell, Denisa Mindruta, and Matthew Edwardsen. 2003. “Building Consensual Institutions: Networks and the National Estuary Program." American Journal of Political Science 47 (1): 143-58.

Scholz, John T., and Cheng-Lung Wang. 2006. "Cooptation or Transformation? Local Policy Networks and Federal Regulatory Enforcement." American Journal of Political Science 50 (1): 81-97.

Shehan, Judy, and Derrick Coley. 2002. Historic Brownfields Bill Becomes Law: Major Victory for Mayors as Lengthy Lobbying Process Pays Off. http://www.usmayors.org/brownfields/history.asp. Accessed December 21, 2009.

Siikamäki, Juha, and Kris Wernstedt. 2008. “Turning Brownfields into Greenspaces: Examining Incentives and Barriers to Revitalization." Journal of Health Politics, Policy and Law 33 (3): 559-93.

Solitare, Laura, and Michael Greenberg. 2002. "Is the U.S. Environmental Protection Agency Brownfields Assessment Pilot Program Environmentally Just?" Environmental Health Perspectives 110 (S2): $249-57$.

Spence, David B. 1997. "Agency Policy Making and Political Control: Modeling Away the Delegation Problem." Journal of Public Administration Research and Theory 7 (2): 199-220.

U.S. Environmental Protection Agency. 2005. State Brownfields and Voluntary Response Programs. Washington, DC: U.S. Environmental Protection Agency, Office of Solid Waste and Emergency Response.

U.S. Government Accountability Office. 2005. Hazardous Waste Programs: Information on Appropriations and Expenditures for Superfund, Brownfields, and Related Programs. Washington, DC: U.S. Government Accountability Office.

Waterman, Richard, Amelia Rouse, and Robert Wright. 1998. "The Venues of Influence: A New Theory of Political Control of the Bureaucracy." Journal of Public Administration Research and Theory 8 (1): 13-38.

Wernstedt, Kris. 2001. "Devolving Superfund to Main Street: Avenues for Local Community Involvement." Journal of the American Planning Association 67 (3): 293-313.

Wernstedt, Kris, and Robert Hersh. 2006. "Brownfields Regulatory Reform and Policy Innovation in Practice." Progress in Planning 65 (1): 2-74.

Wernstedt, Kris, Peter B. Meyer, and Anna Alberini. 2006. “Attracting Private Investment to Contaminated Properties: The Value of Public Interventions." Journal of Policy Analysis and Management 25 (2): 347-69.

Whitford, Andrew B. 2005. "The Pursuit of Political Control by Multiple Principals." Journal of Politics 67 (1): 29-49.

Woolley, John. 1993. “Conflict Among Regulators and the Hypothesis of Congressional Dominance." Journal of Politics 55 (1): 92-113.

Yackee, Susan Webb. 2006. "Sweet-Talking the Fourth Branch: Assessing the Influence of Interest Group Comments on Federal Agency Rulemaking." Journal of Public Administration Research and Theory 16 (1): 103-24. 